\title{
The Learning Model of Information Processing in Building Islamic Characters at State Senior High Schools in East Lombok
}

\author{
*Enti ${ }^{1}$ and Khairani ${ }^{2}$ \\ ${ }^{1}$ Master Program of Geography Education, Universitas Negeri Padang, Indonesia \\ ${ }^{2}$ Geography Department, Universitas Negeri Padang, Indonesia \\ Email: enti_1018@yahoo.co.id
}

*Corresponding Author, Received: March 10, 2019, Revised: April 10, 2019, Accepted: June 10, 2019

This is an open acces article distributed under the Creative Commons 4.0 Attribution License, wich permits unrestricted use, Distribution, and reproduction in any medium provided the original work is properly cited @2017 by author and Universitas Negeri Padang

\begin{abstract}
This research was aimed to know the implementation of information processing learning model in building student's Islamic character at state senior high schools in East Lombok. East Lombok is very famous of its iconic destination of thousand mosques. Its Islamic nature become the reason of the development of Islamic education in high schools in East Lombok. The purpose of this research was two discuss the strengths of information processing learning model in building student's Islamic characters. It was a qualitative research, using a descriptive approach. To collect the data, field observation and interview with sources about the model information were conducted. The result of this research is expected to give a description of the model implementation at state senior high schools in East Lombok.
\end{abstract}

Keywords: Information Processing Learning Model, Islamic Characters

\section{Introduction}

Human progress and development in this globalization era leads to the need of education corresponded to the era. The education should be able to develop student's cognition and characters. Character education aims to develop individual self-potential and create a generation of moral and noble. So, the purpose of education in Indonesia must direct to various human characters, not to academic education only (Kesuma, 2011). Another definition by Sudrajad (2008) explained that character education is a system instilling character values to school's society, including knowledge, awareness or willingness, and an act to practice them. Education can also be defined as "the deliberate use of all dimensions of school life to foster optimal character development". Education plays an important role in changing one's life. Education is obtained through information transfer inside or outside the classroom. As stated in Indonesian Constitution Number 20 Year 2003 about National Education System chapter 1: Education is a conscious and planned effort to realize learning atmosphere and learning process where students actively develop their self-potential in order to have religious spiritual strength, self-control, personality, intelligence, noble character, and some skills necessary for themselves, society, nation and state.

Both chapters above mean that education is not merely about self-personality and self-potential development but more about the way how to get good information for good self potential and personality development. As an Islamic region, education in East Lombok should be able to instill Islamic values in student's characters. To realize an ideal education in east Lombok, the information should be based on Islamic teaching. In the world of education information transformation process is done by using various learning models. To instill those values, schools in East Lombok should be able to design and develop Islamic learning model which is able to bring Islamic information in full. The various implementations mean not being fixated only in lecture method or discussion but also on the improvement of student's understanding and innovation in field of science. More over, the combination of various learning models and 
Islamic characters will produce students who are knowledge able and nobel. One of models that could be developed is Islamic-characterized information processing learning model.

This model is a learning model that emphasizes on the activities of processing information to enhance student's capability in learning. It focuses on the theory cognitive learning. Information processing refers to the process of collecting/accepting stimulus from environment, organizing data, solving problems, finding concepts and solutions, and using verbal and nonverbal symbols. This model relates to the ability of problem solving, productive thinking ability and general intellectual ability. The theory of information processing or cognitive was pioneered by Robert Gagne (1985).He assumed that learning is a really important factor in development. It is the output of processing information. According to Suharnan (2005) perception is a process of using knowledge in one's mind to detect or obtain and interpret stimulus received by sense like eyes, ears, and nose. From that definition into can be said that perception is a process of interpreting information acquired by human sense. This model should have been used in schools in East Lombok Regency because this is very helpful to achieve Islamic characterized learning outcomes. As for the purpose of this research was discussing the benefits from using information processing learning model in building student's Islamic characters at senior high schools in East Lombok.

\section{Method}

This reasearch was conducted at three senior schools, at SMA N1 Sikur, SMA N 1Terara and SMAN 1 Aikmel. These schools were located in East Lombok. The informants were principals, 4 geography teachers and 25 students. It was a qualitative research using descriptive approach. A qualitative research is a research procedure that produces descriptive data, written and spoken, obtained from people and behavior. This research emphasizes on the introduction of types of studio's learning problems, second, the identification of types of stimulus frequently used by teachers, third, the organization of information for concept building, fourth, solution to the problems related to material and Islamic character development and finally, the identification of the format of material summary and Islamic characters. Techniques of data collection were observation and interview. The researcher observed student's way of learning and problems faced by students in learning process. Interview was used for identifying the types of stimulus frequently used bu teachers, understanding the organization of information to develop concepts and solve the problems related to material and islamic character development and identifying the format of material and Islamic character summary. Techniques of data analysis used were: first, reducing the data related to the learning model; second, displaying the data of types of student's learning problems; third, identifying types of stimulus frequently used by teachers organizing information to develop a concept related to the material and character development; fourth, identifying the format of material and Islamic character summary; fifth, the final step was drawing a conclusion about the learning model of information processing in bulding student's islamic characters in East Lombok.

\section{Result and Discussion}

Problems that are often faced by students in the learning process are problems in building the focus of students on subject matter, and problems building learning activeness. Many things are behind this, starting from the environment around, peers and even families. One of the family problems that often aggravates students in the learning process in East Lobok Regency is the weak economic condition of parents, where to relieve parents in meeting the daily needs of many of these high school students who choose to work after school. This condition often makes children lazy to study at home and in the end are also less ready to receive education in the classroom. The condition of parents who also work outside the country as migrant workers also often makes children feel less affection, as a result of this child delinquency also increases. In line with this, Sari (2015) in her research suggests that learning difficulties are not as bad as caused by low intelligence, this is because children with high intelligence also have the potential to experience learning difficulties. Learning difficulties can also be caused by non-intelligence factors, namely factors that originate from the students themselves and the environment around students. These factors include physiological factors (physical condition), psychological factors, family factors, school factors, mass media factors and social environmental factors. Subiyanto (2013) in his study also explained that if parents 
play a role in education, children will show an increase in learning achievement, followed by improved attitudes, socio-emotional stability, discipline, and children's aspirations to learn to the highest level, even helping children when he have worked and have a family.

To overcome the above problems it is very important for a teacher to recognize the character of his students and choose a learning model that builds learning authenticity, and provides understanding and affection to students so that these students are closer to the teacher and school. The condition of East Lombok Regency which is very religious will make it easier to build mental strengthening of students. The closer participants are taught by religion, the easier it will be to instill learning values in their hearts. At present almost every school conducts zuhr prayers in congregation and reciting or reciting the Asmaulhusnah in the morning, as well as imtaq activities on certain Islamic days. This activity is a positive thing for the development of student faith. If this activity is carried out seriously, then to build student success and student interest will be very easy. But in three schools in East Lombok Regency there are still students who have not followed this well, so the problem builds the focus of students on the subject matter, and the problem of building active learning still occurs.

As an area based on Islamic religion, education in East Lombok Regency is also influenced by Islamic teachings. Where before material was given, many teachers first give Islamic advice to their students. The achievement of the Al-qur'an scripture is often tucked in when giving material especially on geographic material, this activity is a form of stimulus or encouragement that is often done by a teacher before starting to provide subject matter. By giving encouragement, it is expected that the student's cognitive process can be built and directed at the subject matter. The stimulus given should be in accordance with the surrounding environmental conditions with the opinion of Asti Nurela (2014) wherein the researchers stated that the environment as a source of learning has a role in fostering spatial attitudes and behavior of students, the environment influences students' spatial attitudes through professional competence. And the theory of the relationship between attitudes and behavior (contingency dependent postulate theory) states that the relationship of attitudes and behavior is highly situational dependent. By understanding the surrounding environment Learners are directed to high-level thinking and critical thinking so that they will be sensitive to the characteristics of the space in which they live. The statement above also implies that the stimulus given should be varied, this is so that students do not feel bored with stimulus that are almost the same every time. If students feel bored at the beginning of the activity of stabilizing the material students will experience difficulties and choose indifferently and do not pay attention to the material provided. This stimulus can be in the form of the use of image, visual media or other things that exist around the students. By building a stimulus in the form of attaining the Qur'an verses and giving pictures or videos related to the material to be discussed, the students' interest in the material will be improved.

Organizing information, finding concepts in each field and solving problems in each material is very important to make perfect knowledge. Almost all teachers use this learning model, and the problem that often arises is the difficulty in controlling students when the discussion process takes place. Using a learning model that is almost always the same makes a child feel bored and turns into a lack of full learning. Information transfer is mostly done by teachers during learning or the teacher is more often a teacher centric, feedback is still lacking by students especially on material that is difficult to describe. Different student backgrounds often make it difficult for teachers to build similarities in concepts for each student, and this will also affect students' success in learning material. Students' achievement in obtaining information is also strongly influenced by the learning resources, where in East Lombok Regency schools learning resources often used are materials designed by teachers through MGMP, and occasionally teachers ask students to search for subject materials on the internet. In general, this has been able to provide learning resources to students, but learning resources from MGMP must always be addressed and based on clear references so that the information provided is more accurate and in accordance with the era. As for learning resources from the internet the teachers often use them as other references, it would be better if the material in the internet is referred to support the material concept and as a guideline in observing arising problems and learning and solving them. In line with this, Abdulah (2012) in his research explained that the use of learning resources is influenced directly by the factors of students' perceptions of learning resources. Students with an understanding of learning resources that are still conventional, generally place teachers and textbooks as the only source of learning. By using media that is designed correctly, the process of organizing information can be done appropriately, even a clear concept of the material can be done, as well as problem solving on each 
material can be done by the students themselves through appropriate reference earning resources. The summary of information at the end of each learning material is very important, this aims to equalize the understanding of all students regarding the material and at the same time ensure that students understand every material. In these high schools in East Lombok Regency, the process of summarizing the material is often done in a way where the teacher and students collectively draw conclusions on the subject matter that has been studied. The process of this conclusion is often started first by the teacher and after that it is just thrown to the students. The summary process of this material can be more varied by giving quizzes at the end of the lesson, so that students are challenged to answer it. Besides that the teacher easily sees the ability of each student for the material they have finished learning. The process of summarizing this material is also meant to ensure that the knowledge that students achieves the highest point without any hesitation or other things that could disturb their intact knowledge.

\section{Conclusion}

The conclusion from the results of this study is that Islamic characterized information processing learning model can be developed in education at high schools in East Lombok Regency. These results of this research include: 1). Problems that are often faced by students in the learning process are student focus on subject matter, and problems in building learning activeness, where these problems are often motivated by family problems. 2). Stimulus that is often used is Islamic advice and reads the Qur'an verses related to the material being studied. 3) Organizing information, finding concepts in each method and solving problems in each material is often done by lecture, discussion or jigsaw. On average, each school uses this method so learning becomes less varied and innovative. 4). The process of summarizing the material is often carried out in a way where the teacher and students collectively draw conclusions on the subject matter that has been studied. This inference process is often started first by the teacher and after that it is done by students. This summary of information will be better done with varied techniques so that each student's knowledge can be measured and observed.

\section{References}

Abdullah Ramli. 2012. Pembelajaran Berbasis Penfaatan Sumber Belajar . Jurnal Ilmiah Ditataktif. Vol. XII No. 2

Gagne, Ellen, D. 1985. The Cognitive Psychology of School Learning. Boston: Little, Brown \& Company.

Kesuma Dharma. 2011. Pendidikan Berkarakter. Bandung. PT Remaja Rosdakarya

Nurela Astih. 2014. Peran Lingkugan Sebagai Sumber Belajar Geografi Dalam Menumbuhkan Sikap dan Perilaku Peserta Didik: Jurnal GEA. Volume 14 Nomor 1, April 2014

Republik Indonesia. 2003.Undang Undang No. 20 Tahun 2003 tentang Sistem Pendidikan Nasional.

Sari Eka Purnama. 2012. Faktor Peyebab Kesulitan Belajar di Kelas X Pada Matapelajaran Geografi : Jurnal Geografi

Subiato Jito. 2013. Peran Keluarga, Sekolah dan Masyrakat dalam Membentuk Karakter Berkualitas : Jurnal LLPG. Vol. 8, No. 2, Agustus 2013

Suharnan. 2005. Psikologi Koknitif. Srikandi. Jakarta 